\title{
IMPACT OF ARAL SEA DRYING ON COTTON PRODUCTIVITY
}

\author{
Esbolova Miyrigul Bazarbaevna \\ Candidate of Agricultural Sciences, Assistant of the Department Farming, Selection and Seed \\ Breeding of Agricultural Crops, Nukus branch of Tashkent State Agrarian University, Nukus, \\ Karakalpakstan, Uzbekistan
}

Article DOI: https://doi.org/10.36713/epra3426

\begin{abstract}
Incorrect use of water resources brought to the drying of Aral Sea. This brought to formation of salty dust deserts. Salty dust aerosols are delivered to adjoining irrigated territories by wind. Soil saltiness increases which negatively influences on the productivity of cotton. For softening negative influence it is recommended to use organic fertilizers in quality of mulch in account of 20-30 $\mathrm{t} / \mathrm{h}$.
\end{abstract}

KEYWORDS: drying, salinization, salty dust aerosols, cotton, yield, organic fertilizers, mulching.

\section{INTRODUCTION}

Situated in the middle of desert The Aral sea had a favorable impact on natural-climatic and environmental conditions of surrounding regions and was humidity regulator over a wide area of the Aral Sea region, protector of dry hot wind, coming from the Southern Desert.

In the result of extensive water use brought to a sharp reduction in river flows of Amudarya and Sirdarya into the Aral sea. The aridity of the climate increased, air humidity decreased by $10-18 \%$, frostfree period reduced by 30-35 days.

At present $25000 \mathrm{~km}^{2}$ of sea floor exposed and coastline has receded by $100-150 \mathrm{~km}$. Subsequently, another powerful source of sand-salt aerosols has emerged in Central Asia, transported by air masses to adjacent territories. Dust hoisted by storms onto the soil surface reduces fertility and therefore adversely affects the productivity of cultivated crops. The main environmental problems of Karakalpakstan under the conditions of extensive economic activity were cotton monoculture. Cotton production in the country as a whole reached 80 percent in the eighties and nineties. It is an unprecedented indicator in the world, although science has shown that cotton above $50-60 \%$ causes humus loss, soil depletion, infertility and eventual land degradation.

\section{METHODS OF CONDUCTING THE EXPERIMENT}

To study the impact of the drying of the Aral Sea on the productivity of cotton and soil fertility, field studies have been carried out on the remoteness $(150-250 \mathrm{~km})$ from the dry seabed of the Aral Sea. Cotton, cultivated in the Central (Khodjeli region) and northern (Kanlikul region) climatic soils of the Republic of Karakalpakstan was selected as the object of study.

The test sites are located in Khodjeli and Kanlikul regions accordingly 250 and 150 kilometers far from the dry seabed of the Aral Sea. The soil of the test plots is more typical for the conditions of the specified zones of the Republic.

C - 4727 cotton varieties were sampled, in row-spacing $60 \mathrm{~cm}$, area of each plot $240 \mathrm{~m}^{2}$ of which $120 \mathrm{~m}^{2}(2.4-50 \mathrm{~m})$ repeated three times, located in one tier.

The test options are as follows:

1. Cotton, normal cultivated conditions.

2. Cotton, closed field $\left(10.2 \mathrm{~m}^{2}\right)$.

3. Cotton, mulching with manure for $10 \mathrm{t} / \mathrm{ha}$ before the first cultivation.

4. Cotton, mulching with manure for $20 \mathrm{t} / \mathrm{ha}$ before the first cultivation.

5. Cotton, mulching with manure for $30 \mathrm{t} / \mathrm{ha}$ before the first cultivation. 


\section{RESEARCH RESULTS AND THEIR DISCUSSION}

The data obtained indicates that salty dust aerosols falling on the cotton fields, adversely affect the growth and development of cotton. Cotton cultivated under normal conditions significantly lags in growth and development from other options, where the additional measures are applied to mitigate the adverse effects of salty dust aerosols.

Effectiveness or influence of those factors during the growing season of cotton is estimated to have an impact on the yield of raw cotton. Differences between options according to cultivation condition was $2.1-0.9 \mathrm{c} / \mathrm{ha}$. In option 1 , where the cotton was cultivated in the usual manner, the raw cotton harvest was $24.1 \mathrm{c} / \mathrm{ha}$. In option 2 , where the cotton was cultivated in a salty dust aerosol protected area was $26.2 \mathrm{c} / \mathrm{ha}$, there was an increase of $2.1 \mathrm{c} / \mathrm{ha}$ over option 1.

The use of organic fertilizers as mulch (options 3,4 and 5) at 10, 20 and $30 \mathrm{t} / \mathrm{ha}$ contributed to an additional 4.2 to $9.0 \mathrm{c} / \mathrm{ha}$ compared to option 1 , that is organic fertilizer largely mitigates the negative effects of salty dust aerosols and improves soil nutrition.

\section{CONCLUSIONS}

Thus, to mitigate the adverse effect of salty dust aerosols on cotton yields and soil fertility options 4 and 5 are economically more effective, where 20 and $30 \mathrm{t} / \mathrm{ha}$ of organic fertilizer were used before the first cultivation of both the Central and Northern areas of the Republic.

\section{REFERENCES}

1. Duhovniy V.A., Razakov P.M. (1988), The Aral Sea in eyes of truth. Journal "Melioration and water management”. №9, p.p: 27.

2. Likov A.M. (1988), Reproduction of oil organic matter in modern farming systems. №9, p.p: 20-22.

3. Ismaylov U.E. (2014), Impact of Aral sea drying on cotton yields. Scientific report on the project KXA-7-007 for 2012-2014. 